\title{
Pemberitaan Kampanye Pemilihan Presiden 2019 Di Media Siber dan Penerapan Elemen Jurnalisme (Analisis Framing Pada Okezone.Com dan Suara.Com)
}

\author{
Esti Sri Handayani, Ahmad Junaidi \\ Esti.915150183@stu.untar.ac.id,ahmadd@fikom.untar.ac.id
}

Fakultas Ilmu Komunikasi Universitas Tarumanagara

\begin{abstract}
The campaigns for 2019 General Election certainly would not escape the eyes of the media. Since the enactment of Act No. 40 of the year 1999 about the press, political communication system and the relationship between the Government with the press can take balanced. So that a variety forms of mass media including online media in Indonesia, presents a variety of information and news related to the general election campaign. The purpose of this research is to find out how okezone.com and suara.com reconstructed a reality to frame an event into news as well as to find out how application elements of journalism in framing the news. The approach in this research is descriptive-qualitative, and the research methods in this research is Framing Analysis model Zhongdan Pan \& Kosicki, then the data in the framework of the framing that had been described, will be examined using the elements of Journalism by Bill Kovach. Data collection in this research using a non-participant observations on each of the media, the study of literature, online data searches as well as supported by interviews with informants. Conclusion in this research is that obvious okezone.com are in the line behind the incumbent. While suara.com who claimed themselves as the independent media, precisely on some of the news indicated their side in Prabowo. Then, the application of rule elements of Journalism is still pretty good, because during the news of the 2019 general election campaign that had been analyzed and reviewed, only the 8th points that they frequently neglect.
\end{abstract}

Keywords: Framing Analysis, 2019 General Election, Elements of Journalism, Online Media

\begin{abstract}
Abstrak
Proses kampanye Pemilu 2019 tidak luput dari mata media. Undang Undang No.40 Tahun 1999 tentang Pers, sistem komunikasi politik dan relasi antara pemerintah dengan pers dapat berlangsung seimbang. Berbagai media massa termasuk media daring di Indonesia, menyajikan berbagai informasi dan berita terkait dengan kampanye pemilihan umum. Tujuan penelitian ini adalah mengetahui bagaimana okezone.com dan suara.com merekonstruksikan sebuah realita untuk membingkai peristiwa menjadi berita serta mengetahui bagaimana aplikasi elemen jurnalisme dalam pembingkaian berita. Penelitian ini menggunakan pendekatan kualitatif deskriptif dengan metode penelitian Analisis Framing Model Zhongdan Pan \& Kosicki. Data dalam kerangka framing dikaji menggunakan Elemen-Elemen Jurnalisme Bill Kovach. Pengumpulan data menggunakan observasi non-partisipan pada masing-masing media, studi kepustakaan, penelusuran data daring serta didukung wawancara informan. Kesimpulan penelitian ini adalah okezone.com berada di garis belakang kubu petahana. Sementara suara.com yang mengklaim sebagai media independen, beberapa pemberitaan mengindikasikan keberpihakan pada kubu Prabowo. Penerapan kaidah Elemen Jurnalisme cukup baik, karena selama pemberitaan tentang kampanye Pilpres 2019. Namun, pada poin ke-8 sering terindikasi adanya pengabaian dalam pemberitaan tentang kampanye Pilpres 2019.
\end{abstract}

Kata Kunci: Analisis Framing, Pemilihan Umum 2019, Elemen-elemen Jurnalisme, Media Siber 


\section{Pendahuluan}

Komunikasi selalu digunakan dan mempunyai peran yang penting dalam segala aspek kehidupan manusia, salah satu jenis komunikasi yang berperan penting adalah komunikasi massa. Rakhmat (dalam Ardianto, 2007) mengatakan bahwa komunikasi massa diartikan sebagai jenis komunikasi yang ditujukan kepada sejumlah khalayak yang tersebar, heterogen dan anonim melalui media cetak atau elektronik sehingga pesan yang sama dapat diterima secara serempak dan sesaat. Kemudian, Hikmat (2018) mengatakan bahwa komunikasi massa merupakan proses komunikasi melalui media massa modern yang meliputi surat kabar, majalah, siaran radio, siaran televisi dan media sosial atau dunia maya dengan teknologi internet. Komunikasi massa menyampaikan informasi, gagasan dan sikap kepada khalayak yang beragam dalam jumlah yang banyak dengan menggunakan media.

Ketika berbicara mengenai media, sebagian besar yang terlintas di benak kita adalah media seperti radio, televisi, film dan koran. Namun, seiring dengan berkembangnya zaman dan teknologi, media juga dapat berarti sebagai media baru yang terkait dengan penggunaan teknologi media interaktif seperti internet. (Straubhaar et al, 2010 dalam jurnal penelitian Suzy Azeharie). Media baru akrab dengan sebutan media dalam jaringan (daring), karena memerlukan koneksi internet dalam penggunaannya. Kemunculan media baru yang merupakan hasil dari perkembangan teknologi dan konvergensi media, dinilai memiliki keunikan tersendiri. Karena dengan instan dan mudah, masyarakat dapat mengakses kanal-kanal berita pilihannya dari berbagai sumber, di mana saja dan kapan saja hanya dengan koneksi internet dalam sebuah gawai maupun komputer.

Jika dilihat dari perspektif politik, dikutip dari Eriyanto (2005) media massa telah menjadi elemen penting dalam proses demokrasi karena menyediakan ruang untuk debat publik, menjadikan calon pemimpin dikenal oleh masyarakat menjelang kegiatan kampanye pemilihan umum. Proses kampanye jelang pemilu 2019 tentu tidak akan luput dari mata media. Sejak diberlakukannya UU No.40 tahun 1999 tentang pers, sistem komunikasi politik dan relasi antara pemerintah dengan pers dapat berlangsung seimbang. Sehingga berbagai macam bentuk media massa termasuk media daring di Indonesia, menyajikan macam-macam informasi dan berita terkait dengan kampanye pemilihan umum.

Berkaitan dengan hal tersebut, belakangan ini di media daring tersedia berbagai macam berita tentang kampanye Pemilihan Umum Presiden 2019 mendatang. Beritaberita yang disajikan oleh kanal berita di media daring ini, tentu harus memperhatikan kaidah-kaidah pada elemen jurnalisme sebagai bentuk kebebasan pers yang bertanggung jawab sesuai dengan UU No.40 tahun 1999 tentang Pers. Berkaitan dengan hal tersebut, belakangan ini di media daring tersedia berbagai macam berita tentang Pemilihan Umum Presiden 2019 mendatang. Berita-berita yang disajikan oleh kanal berita di media daring ini, tentu harus memperhatikan kaidah-kaidah pada elemen jurnalisme sebagai bentuk kebebasan pers yang bertanggung jawab.

Dari serangkaian berita yang disajikan oleh media terpilih penulis (okezone.com dan suara.com), maka tujuan dari penelitian ini adalah untuk mengetahui bagaimana kedua media membingkai beritanya dan untuk mengetahui bagaimana penerapan elemen jurnalisme pada Pemberitaan Pemilihan Presiden 2019. 


\section{Metode Penelitian}

Pendekatan dalam penelitian ini adalah kualitatif deskriptif, dengan metode analisis framing model Zhondang Pan dan Kosicki. Sudibyo (dalam Sobur, 2013a) mengatakan bahwa pada ranah studi komunikasi, analisis framing mewakili tradisi yang mengedepankan pendekatan atau perspektif multidisipliner untuk menganalisis fenomena atau aktivitas komunikasi.

Zhongdan Pan dan Gerald M Kosicki (dalam Sobur, 2013b) mengoperasionalisasikan empat dimensi struktural teks berita sebagai perangkat framing, yaitu sintaksis, skrip, tematik dan retoris. Struktur sintaksis berhubungan dengan bagaimana wartawan menyusun peristiwa mulai dari pernyataan, opini, kutipan, pengamatan atas peristiwa ke dalam bentuk susunan kisah berita. Dengan demikian, struktur sintaksis ini bisa diamati dari bagian headline yang dipilih, lead yang dipakai, latar informasi yang dijadikan sandaran hingga sumber yang dikutip.

Sementara itu, struktur skrip melihat bagaimana strategi bercerita atau bertutur yang dipakai wartawan dalam mengemas peristiwa. Kemudian, struktur tematik berhubungan dengan cara wartawan mengungkapkan pandangannya atas peristiwa ke dalam proposisi, kalimat atau hubungan antar kalimat yang membentuk teks secara keseluruhan. Struktur ini akan melihat bagaimana pemahaman itu diwujudkan ke daam bentuk yang lebih kecil. Lalu, struktur retoris berhubungan dengan cara wartawan menekankan arti tertentu. Dengan kata lain, struktur retoris melihat pemakaian pilihan kata, idiom, grafik, gambar yang juga dipakai guna memberi penekanan pada arti tertentu. Keempat dimensi struktural ini membentuk semacam tema yang mempertautkan elemen-elemen semantik narasi berita dalam suatu koherensi global. Model ini berasumsi bahwa setiap berita mempunyai frame yang berfungsi sebagai pusat organisasi ide.

Berdasarkan penjelasan Burhan Bungin (2011) bahwa objek dan informan penelitian kualitatif adalah menjelaskan objek penelitian yang fokus dan apa yang menjadi sasaran penelitian. Informan penelitian adalah subjek yang memahami informasi objek penelitian sebagai pelaku maupun orang lain yang memahami objek penelitian. Bungin juga menambahkan bahwa para ahli yang membantu melengkapi data penelitian disebut sebagai informan sekunder. Bungin juga menjelaskan ada tiga cara yang bisa digunakan untuk menentukan informan dalam penelitian kualitatif yaitu prosedur purposif, prosedur kuota, dan prosedur snowball. Maka objek dalam penelitian ini, penulis menggunakan prosedur kuota. Karena penulis telah memutuskan saat merancang penelitian, akan ada dua objek dari media yang berbeda dan satu orang ahli sebagai informan sekunder yang akan diwawancarai agar penelitian lebih berfokus dan data yang diperoleh bisa seimbang.

Teknik pengumpulan data dalam penelitian ini dilakukan dengan observasi nonpartisipan pada tiap-tiap konten media mengenai pemberitaan pemilihan presiden 2019 dalam kurun waktu tiga bulan (Agustus-Oktober), yang didukung dengan proses wawancara dengan narasumber okezone.com, suara.com dan dewan pers. 


\section{Hasil Temuan dan Diskusi}

Tabel 1. Pemberitaan Okezone.com Bulan Agustus

\begin{tabular}{lclcr}
\hline No & Hari, Tanggal & \multicolumn{3}{c}{ Judul Berita } \\
\hline 1 & 9 Agustus 2018 & $\begin{array}{l}\text { Jokowi: } \\
\text { mendampingi }\end{array}$ & Maruf & amin \\
& & $\begin{array}{l}\text { saya } \\
\text { cawapres }\end{array}$ & & \\
& & Sandiaga & Uno jadi cawapres \\
2 & 9 Agustus 2018 & Prabowo Subianto di Pilpres 2019 \\
\hline
\end{tabular}

Tabel 2. Pemberitaan Okezone.com Bulan September

\begin{tabular}{lrl}
\hline No & Hari, Tanggal & \multicolumn{1}{c}{ Judul Berita } \\
\hline 1 & 3 September 2018 & Jelang Pilpres 2019, lagi-lagi \\
& & beredar uang berstempel Prabowo \\
2 & 2 September 2018 & Jokowi saksikan closing ceremony \\
& & Asian Games 2018 dari Lombok \\
\hline
\end{tabular}

Tabel 3. Pemberitaan Okezone.com Bulan Oktober

\begin{tabular}{lcll}
\hline No & \multicolumn{1}{c}{ Hari, Tanggal } & \multicolumn{1}{c}{ Judul Berita } \\
\hline 1 & 24 Oktober 2018 & Elektabilitas Prabowo-Sandi turun \\
& & $\begin{array}{l}\text { pasca-kasus ratna sarumpaet, ini } \\
\text { kata tim pemenangan }\end{array}$ \\
& & Prabowo minta maaf telah \\
& sebarkan kebohongan ratna \\
& sarumpaet & \\
\hline
\end{tabular}

Tabel 4. Pemberitaan Suara.com Bulan Agustus

\begin{tabular}{lcl}
\hline No & \multicolumn{1}{c}{ Hari, Tanggal } & \multicolumn{1}{c}{ Judul Berita } \\
\hline 1 & 9 Agustus 2018 & $\begin{array}{l}\text { Jokowi pilih maruf amin sebagai } \\
\text { cawapres }\end{array}$ \\
2 & 9 Agustus 2018 & $\begin{array}{l}\text { Sandiaga uno akhirnya resmi jadi } \\
\text { cawapres prabowo subianto }\end{array}$ \\
\hline
\end{tabular}

Tabel 5. Pemberitaan Suara.com Bulan September

\begin{tabular}{lcl}
\hline No & Hari, Tanggal & \multicolumn{1}{c}{ Judul Berita } \\
\hline 1 & 3 September 2018 & $\begin{array}{l}\text { Heboh uang dari atm berstempel } \\
\text { prabowo di tangerang }\end{array}$ \\
2 & 2 September 2018 & $\begin{array}{l}\text { Jokowi nonton penutupan asian } \\
\text { games bersama korban gempa } \\
\end{array}$ \\
& & lombok \\
\hline
\end{tabular}


Esti Sri Handayani, Ahmad Junaidi: Pemberitaan Kampanye Pemilihan Presiden 2019 Di Media Siber dan Penerapan Elemen Jurnalisme (Analisis Framing Pada Okezone.Com dan Suara.Com)

Tabel 6. Pemberitaan Suara.com Bulan Oktober

\begin{tabular}{|c|c|c|}
\hline $\mathrm{No}$ & Hari, Tanggal & Judul Berita \\
\hline 7 & 5 oktober 2018 & $\begin{array}{l}\text { Berkat hoaks, jubir BPN sebut } \\
\text { elektabilitas prabowo bakal naik }\end{array}$ \\
\hline 2 & 3 oktober 2018 & $\begin{array}{l}\text { Terpancing hoaks ratna sarumpaet, } \\
\text { prabowo minta maaf ke publik }\end{array}$ \\
\hline
\end{tabular}

Penggunaan bahasa dan pilihan diksi sangat berkontribusi untuk menentukan konstruksi realitas pada media massa, dalam kasus ini portal berita daring. Hal tersebut pada akhirnya dapat menunjukkan sikap media okezone.com dan suara.com pada pemberitaan tentang kampanye pilpres 2019.

Ditinjau dari hasil temuan yang didapat penulis di atas, pada dasarnya telah menyediakan dua sudut pandang yang berbeda pada pemberitaannya. Kemudian, tidak dapat dihindari, judul berita dan isi berita yang disajikan sebagian lebih menonjolkan satu sudut pandang tertentu dibanding sudut pandang lainnya.

Empat dari duabelas berita yang penulis analisis menggunakan Analisis Framing, mengindikasikan keberpihakan media kepada masing-masing kubu. Beritaberita yang terindikasi memiliki keberpihakan adalah berita dengan headline "Berkat Hoax, Jubir BPN Sebut Elektabilitas Prabowo Bakal Naik." Berita ini berasal dari suara.com, tayang pada Jumat 9 Oktober 2018, kemudian berdasarkan unsur skrip dan tematik dalam kerangka framing Pan Kosicki, suara.com dalam hal ini telah menanamkan fakta dari data yang dipunya dengan cara menonjolkan pendapat juru bicara BPN yang mengatakan bahwa pasca jasus hoax, ia percaya elektabilitas Prabowo akan naik. Dari diksi-diksi yang digunakan sepanjang isi berita, suara ingin para pembaca terfokus pada hal itu saja, sementara dilansir dari LSI (Lembaga Survei Indonesia), mengatakan bahwa justru elektabilitas Prabowo menurun.

Berita selanjutnya masih mengenai topik yang sama dari portal berita yang berbeda, yaitu okezone.com pada 24 Oktober 2018 dengan headline "Elektabilitas prabowo-sandi turun pasca-kasus ratna sarumpaet, ini kata tim pemenangan". Okezone dalam hal ini ingin menanamkan fakta dalam benak masyarakat berdasarkan data survei dari LSI, bahwa kasus hoax tersebut membuat elektabilitas Prabowo menurun dan elektabilitas Jokowi justru meningkat, terbukti pada kalimat pernyataan di akhir berita.

Kemudian, ada berita dengan topik permintaan maaf dari Prabowo kepada Publik. Suara.com memilih headline yang berbunyi "Terpancing hoax ratna sarumpaet, prabowo minta maaf ke publik" dan tayang pada 3 Oktober 2018. Dalam hal ini suara telah merekonstruksikan peristiwa dan ingin menanamkan fakta baru pada khalayak bahwa Prabowo adalah juga korban dari berita bohong tentang Ratna Sarumpaet, hal tersebut terbukti pada pemilihan judul yang menggunakan kata "terpancing" yang secara kiasan berarti terjebak sebagai korban.

Sementara itu, dengan topik yang sama, okezone.com memilih headline yang berbunyi "Prabowo minta maaf telah sebarkan kebohongan ratna sarumpaet" dan tayang pada hari yang sama. Dalam hal ini, okezone telah menanamkan fakta berdasarkan data yang dipunya bahwa Prabowo juga ikut menyebarkan hoax Ratna Sarumpaet, kemudian Prabowo meminta maaf karena telah ikut menyebarkannya. Kemudian, jika suara.com dalam tubuh beritanya lebih menonjolkan tindakan Prabowo pasca kasus hoax atas Ratna Sarumpaet, maka okezone.com dalam tubuh beritanya lebih menonjolkan pada tindakan Prabowo ketika kasus hoax ini masih berupa kasus dugaan penganiayaan, yang ingin menemui Kapolri lantaran kasus ini. 
Setelah berita-berita tersebut telah penulis analisis menggunakan Analisis Framing, penulis mengkajinya dengan Elemen Jurnalisme Bill Kovach untuk diketahui apakah berita yang ditayangkan masih memerhatikan kaidah-kaidah Elemen Jurnalisme. Setelah mengkajinya, penulis menemukan empat berita yang terindikasi mengabaikan Elemen Jurnalisme, berita-berita tersebut meliputi berita yang berjudul "Jokowi Pilih Maruf Amin Sebagai Cawapres" dari suara.com tayang pada 9 Agustus 2018. Berita ini terindikasi mengabaikan Elemen Jurnalisme karena pada tubuh berita hanya menyajikan kutipan dari akun twitter dari anggota Sekjen PKB dan tidak menyajikan kutipan langsung dari pihak yang bersangkutan, sehingga berita ini terindikasi mengabaikan Elemen Jurnalisme poin ke-8 tentang berita yang komprehensif dan proporsional.

Berita kedua datang dari okezone.com dengan judul "Sandiaga Uno Jadi Cawapres Prabowo Subianto di Pilpres 2019" dan tayang pada hari yang sama. Berita ini terindikasi mengabaikan Elemen Jurnalisme karena pada tubuh beritanya hanya berisi pernyataan dan interpretasi yang dibuat wartawan berdasarkan data yang didapat di lapangan, tanpa kutipan langsung dari narasumber pihak yang bersangkutan, sehingga Elemen Jurnalisme poin ke-8 pada berita ini juga terindikasi diabaikan.

Kemudian berita dengan topik beredarnya uang dengan stempel Prabowo. Mengenai topik ini, okezone memilih headline "Jelang Pilpres 2019, lagi-lagi beredar uang berstempel Prabowo" sementara suara memilih headline "Heboh Uang dari ATM Berstempel Prabowo di Tangerang", kedua berita tayang pada hari yang sama dan terindikasi mengabaikan Elemen Jurnalisme karena keduanya hanya menyajikan kutipan dari narasumber saksi, tanpa mencantumkan pernyataan atau kutipan langsung dari pihak yang bersangkutan dengan kasus ini. Kemudian, pemilihan diksi "Heboh" pada suara.com, jika merujuk definisi pada Kamus Besar Bahasa Indonesia berarti sesuatu yang menggemparkan orang banyak, maka menjadi judul yang miss-leading dengan tubuh beritanya, karena di dalam tubuh berita dijelaskan yang menerima uang berstempel Prabowo itu hanya satu orang saja.

Berita selanjutnya yang terindikasi mengabaikan Elemen Jurnalisme datang dari okezone.com dengan headline "Jokowi Saksikan Closing Ceremony Asian Games 2018 dari Lombok", hal tersebut dikarenakan pada tubuh berita menyajikan kutipan dari sumber yang tidak mau disebutkan identitasnya. Sehingga hal tersebut terindikasi mengabaikan Elemen Jurnalisme poin ke-8 tentang keproporsionalan berita.

"Media seharusnya tidak memihak dan lepas dari kepentingan politik pemiliknya. Sesuai dengan panduan Buku Saku Wartawan yang diterbitkan oleh Dewan Pers. " - Stanley

\section{Simpulan}

Framing yang dilakukan kedua media mengindikasikan sikap dan keberpihakan media kepada kedua belah kubu. Hal tersebut terlihat dari beberapa hal yang ditonjolkan pada rekonstruksi peristiwanya dalam penyajian berita yang telah dibedah pada hasil temuan dan pembahasan. Dalam hal ini, berdasarkan analisis framing yang telah dilakukan penulis, maka kesimpulan yang didapat adalah bahwa okezone.com sudah jelas berada di garis belakang kubu petahana. Sementara suara.com yang mengklaim medianya independen, justru pada beberapa pemberitaannya mengindikasikan keberpihakannya pada kubu Prabowo. Hal tersebut sejalan dengan wawancara yang penulis lakukan dengan Redaktur Pelaksana suara.com yang mengatakan bahwa meskipun pemiliknya independen, tidak ada keberpihakan politik, 
tidak dimiliki konglomerasi dan tidak tercatat dalam tim sukses pasangan calon presiden dan calon wakil presiden, belum tentu menjadi jaminan bahwa suara.com tidak berpihak ke Prabowo.

Penerapan kaidah Elemen Jurnalisme masih cukup baik, karena selama pemberitaan tentang Kampanye Pilpres 2019 yang telah penulis analisis dan kaji, hanya poin ke-8 yang sering terindikasi adanya pengabaian dalam pemberitaannya.

Saran yang bisa penulis berikan kepada praktisi jurnalis di media adalah ketika merekonstruksikan peristiwa dari sudut pandang yang berbeda, ingat selalu dengan kaidah elemen jurnalisme. Berkaitan dengan penerapan elemen jurnalisme, hal itu memiliki urgensi untuk dilakukan penelitian lebih lanjut agar dapat diketahui apakah elemen-elemen tersebut masih relevan untuk dipraktikan di era yang serba cepat ini. Terlebih, pada elemen jurnalisme poin ke-2 tentang loyalitas jurnalis kepada warga dan poin ke-4 tentang independensi media terhadap pihak yang mereka liput, di tengah era konglomerasi media saat ini.

\section{Ucapan Terima Kasih}

Ucapan terima kasih diberikan kepada Fakultas Ilmu Komunikasi Universitas Tarumanagara, dosen pembimbing Ahmad Junaidi, S.S., M.Si. selaku penulis kedua dalam jurnal ini. Terimakasih kepada para narasumber Pak Pebriansyah, Pak Vetra dan Pak Yosep Adi Prasetyo, serta semua pihak yang telah mendukung dan membantu dalam penelitian ini.

\section{Daftar Pustaka}

Ardianto, Elvinaro. (2007). Komunikasi massa: suatu pengantar. Bandung: Simbiosis Rekatama Media

Azeharie, S. (2016). Analisis Penggunaan Twitter Sebagai Media Komunikasi Selebritis Di Jakarta. Jurnal Komunikasi, 6(2), 83-98. Retrieved from https://journal.untar.ac.id/index.php/komunikasi/article/view/35/17

Bungin, Burhan. (2013). Metodologi penelitian sosial \& ekonomi: format-format kuantitatif dan kualitatif untuk studi sosiologi, kebijakan publik, komunikasi, manajemen dan pemasaran. Jakarta: Kencana Prenada Media Group

Eriyanto. (2011). Analisis framing. Yogyakarta: Lkis Group

Hikmat, M. (2018). Jurnalistik: literary journalism. Jakarta Timur: Prenadamedia group

Paramita, S. (2018). Framing Portal Berita Dalam Isu Akulturasi Kampung KNG Bogor. Jurnal Muara Ilmu Sosial, Humaniora dan Seni, 2(1), 14-23. Retrieved from https://journal.untar.ac.id/index.php/jmishumsen/article/view/2057/1148

Sobur, Alex. (2009). Analisis teks media. Bandung: PT Remaja Rosdakarya

https://news.okezone.com/read/2018/08/09/605/1934264/jokowi-kh-maruf-aminmendampingi-saya-sebagai-cawapres (dikunjungi pada 31 Agustus 2018, 19.03)

https://news.okezone.com/read/2018/08/09/605/1934406/sandiaga-uno-jadicawapres-prabowo-subianto-di-pilpres-2019 (dikunjungi pada 31 Agustus 2018, 18.25 WIB)

https://www.suara.com/foto/2018/08/10/101304/prabowo-resmi-gandeng-sandiagauno-sebagai-cawapres (dikunjungi pada 31 Agustus 2018, 18.41 WIB)

https://www.suara.com/news/2018/08/09/180156/jokowi-pilih-maruf-amin-sebagaicawapres (dikunjungi pada 31 Agustus 2018, 19.27 WIB) 
https://news.okezone.com/read/2018/09/03/338/1945242/jelang-pilpres-2019-lagilagi-beredar-uang-berstempel-prabowo (dikunjungi pada 30 September 2018, 11.59 WIB)

https://sports.okezone.com/read/2018/09/02/601/1944873/jokowi-saksikan-closingceremony-asian-games-2018-dari-lombok (dikunjungi pada 30 September 2018, 14.02 WIB)

https://www.suara.com/news/2018/09/02/061120/jokowi-nonton-penutupan-asiangames-bersama-korban-gempa-lombok (dikunjungi pada 30 September 2018, 15.07 WIB)

https://www.suara.com/news/2018/09/03/101054/heboh-uang-dari-atm-berstempelprabowo-di-tangerang (dikunjungi pada 30 September 2018, 10.10 WIB)

https://news.okezone.com/read/2018/10/03/337/1959349/prabowo-minta-maaf-telahsebarkan-kebohongan-ratna-sarumpaet (dikunjungi pada 1 November 2018, 9.28 WIB)

https://news.okezone.com/read/2018/10/24/605/1968169/elektabilitas-prabowosandi-turun-pasca-kasus-ratna-sarumpaet-ini-kata-tim-pemenangan (dikunjungi pada 30 Oktober, 21.17 WIB)

https://www.suara.com/news/2018/10/03/221304/terpancing-hoaks-ratna-sarumpaetprabowo-minta-maaf-ke-publik (dikunjungi pada 1 November 2018, 8.40 WIB) https://www.suara.com/news/2018/10/05/211158/berkat-hoaks-jubir-bpn-sebutelektabilitas-prabowo-bakal-naik (dikunjungi pada 30 Oktober 2018, 19.54 WIB) 